\title{
Inhibitory Effect of Spermidine with Antioxidant Activity on Oxidative Stress in Human Dermal Fibroblasts
}

In-Hwan Park and Moon-Moo Kim*

Department of Chemistry, Dong-Eui University, Busan 614-714, Korea

Received January 26, 2011 /Accepted February 9, 2011

\begin{abstract}
Spermidine is a ubiquitous polycation that is synthesized from putrescine, which serves as a precursor of spermine. In recent years, spermidine was found to be a polyamine that plays an important role in longevity. Reactive oxygen species (ROS) such as hydroxyl radical, superoxide and hydrogen peroxide have been shown to be involved in various pathogenic processes as well as aging. The direct scavenging effect of spermidine on DPPH radical, $\mathrm{H}_{2} \mathrm{O}_{2}$ and hydroxyl radical, and its protective effect against DNA oxidation related to oxidative stress were evaluated in vitro. It was observed that spermidine exhibits scavenging activities on DPPH radical and $\mathrm{H}_{2} \mathrm{O}_{2}$ above $500 \mu \mathrm{M}$. Spermidine was especially effective in exerting a scavenging activity on hydroxyl radical. In addition, spermidine at 1000 $\mu \mathrm{M}$ showed a clear protective effect against DNA oxidation. Furthermore, the expression level of antioxidant enzymes such as superoxide dismutase in humam dermal fibroblasts increased in the presence of spermidine compared with blank group. These results suggest that spermidine can be used as an antioxidant to prevent ROS-related diseases including inflammation, cancer and aging.
\end{abstract}

Key words : Spermidine, superoxide dismutase, reactive oxygen species (ROS), human dermal fibroblast

\section{서 론}

최근 생활환경과 식생활의 변화 등으로 현대에는 각종 성인 병 및 노화에 관여하는 활성산소에 대한 관심이 증가하고 있 다. 인체 내에는 안정한 상태의 산소가 생화학적 기전에 의하 여 superoxide anion radical, hydroxyl radical, hydrogen peroxide radical 및 singlet oxygen과 같은 반응성이 큰 활성산소 (reactive oxygen species)로 전환된다[21,36]. 이들 활성 산소 는 세포 구성 성분들인 지질, 단백질, 탄수화물 및 DNA와 반 응하여 산화적 손상 및 효소활성을 변화시켜 뇌졸중 및 파킨 슨씨 병과 같은 뇌 질환뿐만 아니라 심장질환, 허혈, 동맥경화, 암 등과 같은 각종 질병을 일으키는 원인이 되기도 한다. 활성 산소종은 또한 생체조직을 손상시킬 뿐만 아니라 노화를 촉진 시킨다고 보고 되어 있다[23]. 따라서 생체 내에서 활성산소를 조절 할 수 있는 항산화제의 개발에 대한 필요성이 강조되고 있다. 전통적으로 잘 알려진 항산화제로는 vitamin C 및 $\mathrm{E}$ 를 비롯하여 폴리 페놀 화합물로 resveratrol, propolis, eugenol, curcumin 등이 알려져 있다 $[15,17,27,31,33]$. Spermidine은 spermine, putrescine과 함께 polyamine에 속하며, 사람의 정 자와 포도 열매에서 많이 발견되는 선형 분자로서 세포성장, 성숙, 항노화 및 항산화 과정에 많이 관여하고 있다[39]. 뿐만 아니라 spermidine은 다양한 환경적인 스트레스를 차단하는

*Corresponding author

Tel : +82-51-890-1511, Fax : +82-51-890-2620

E-mail : mmkim@deu.ac.kr
데 중요한 역할을 한다[1]. 더욱이 spermidine은 산화적 스트 레스뿐만 아니라 중금속의 독성 및 결핍현상, 염분, 냉기로부 터 오는 스트레스에 대한 보호 효과가 있는 것으로 보고되고 있다 $[5,11,34]$. 최근에는 초파리나 효모에 spermidine을 먹이 면 3 4배 정도 수명이 연장 된다고 보고 되었다[8]. 이러한 항노화 효과는 spermidine의 활성산소 소거능이 있다는 보고 $[12,18,19]$ 와 연관성이 있는 것으로 판단된다. 그러나 spermidine이 항산화 관련 기능적 소재로 입증되기 위해서는 보다 많은 자료의 추가가 필요한 실정이다. 그러므로 본 연구에서 는 spermidine의 항산화 효과와 그 작용기전을 구체적으로 알아보고 spermidime을 항산화제로 기능성 바이오 소재로 개 발하는 자료로 활용하고자 본 연구를 수행 하였다.

\section{재료 및 방법}

재료 및 시료의 제조

세포배양을 위한 Dulbecco's Modified Eagle's Medium (DMEM), Trypsin-EDTA, penicillin/streptomycin/amphotericin (각각 $10,000 \mathrm{U} / \mathrm{ml}, 10,000 \mu \mathrm{g} / \mathrm{ml}$ 및 2,500 $\mu \mathrm{g} / \mathrm{ml}$ ), fetal bovine serum (FBS) 시약은 Gibco BRL (Grand island, NY, USA)로 부터 구입하였다. 사람피부섬유아세포(Human Dermal Fibroblasts, HDFs)는 (주) LG 생활건강 기술원으로 부 터 제공받았다. MTT reagent, gelatin, agarose와 spermidine 기타시약은 Sigma Chemical Co. (St. Louis, MO, USA)로 부터 구입하였다. 


\section{DPPH radical assay}

Brand-Williams [4,16] 실험방법을 변형하여 1,1-diphenyl-2-picrylhydrazyl (DPPH) radical에 대한 spermidine 의 소거능력을 측정하였다. 시험농도의 spermidine를 $\mathrm{DPPH}$ 용액을 가하여 $10 \mathrm{sec}$ 동안 잘 혼합한 다음, 실온에서 $20 \mathrm{~min}$ 동안 반응시킨 후 $525 \mathrm{~nm}$ 에서 흡광도를 측정하였다. $\mathrm{DPPH}$ radical 함량은 시료 첨 가군과 대조군의 흡광도 비를 \% 값으 로 환산하여 나타내었다.

\section{Hydrogen Peroxide Scavenging Assay}

Choi 등[3]의 실험방법을 변형하여 hydrogen peroxide에 대한 소거활성을 측정하였다. $80 \mu \mathrm{l}$ 의 spermidine, $20 \mu \mathrm{l}$ 의 10 $\mathrm{mM}$ hydrogen peroxide 및 $100 \mu \mathrm{l}$ 의 $0.01 \mathrm{M}$ 인산완충용액 (pH5.0)을 $37^{\circ} \mathrm{C}$ 에서 $5 \mathrm{~min}$ 동안 반응 시켰다. 그 후, $15 \mu \mathrm{l}$ 의 $1.25 \mathrm{mM}$ ABTS 및 $30 \mu \mathrm{l}$ 의 peroxidase $37^{\circ} \mathrm{C}$ 에서 $10 \mathrm{~min}$ 동안 반응시켜 $405 \mathrm{~nm}$ 에서 흡광도를 측정하였으며 항산화 활성은 시료 첨가 전후의 흡광도 비를 \% 값으로 환산하였다.

\section{Hydroxyl radical assay}

Chung 등 [37]의 실험방법을 변형하여 hydroxyl radical을 측정하였다. $50 \mu \mathrm{l}$ 의 $10 \mathrm{mM} \mathrm{FeSO}$ 와 $50 \mu \mathrm{l}$ 의 $10 \mathrm{mM} \mathrm{H}_{2} \mathrm{O}_{2}$ 를 이용한 Fenton 반응으로 hydroxyl radical를 발생시켰다. 발생된 radical을 $25 \mu \mathrm{l}$ 의 $10 \mathrm{mM}$ EDTA, $25 \mu \mathrm{l}$ 의 $10 \mathrm{mM}$ 2-deoxyribose, $150 \mu$ l의 $0.1 \mathrm{M}$ phosphate buffer( $\mathrm{pH}$ 7.4)의 존재 하에서 시험농도의 spermidine과 반응시킨 다음 $37^{\circ} \mathrm{C}$ 에서 4 $\mathrm{hr}$ 간 동안 반응시켰다. 여기 에 $250 \mu \mathrm{l}$ 의 $2.8 \% \quad \mathrm{TCA}$ (trichloroacetic acid) 및 $250 \mu \mathrm{l}$ 의 1\% TBA (thiobabituric acid) 를 첨가한 후에 $100^{\circ} \mathrm{C}$ 로 가열하였다. 그 후 상온에서 식힌 다 음 $1,000 \times g$ 에서 $5 \mathrm{~min}$ 동안 원심분리 하였다. 회수한 상등액 은 $532 \mathrm{~nm}$ 에서 흡광도를 측정하였으며 항산화 활성은 시료 첨가 전후의 흡광도 비를 \% 값으로 환산하였다.

\section{환원력 assay}

Oyaizu [32]의 방법에 따라 측정하였다. 시료 $1 \mathrm{ml}$ 에 $\mathrm{pH}$ 6.6 의 $200 \mathrm{mM}$ 인산 완충액 및 $1 \%$ 의 potassium ferricyanide를 각 $1 \mathrm{ml}$ 씩 차례로 가하여 교반한 후 $50^{\circ} \mathrm{C}$ 의 수욕상에서 20 $\min$ 동안 반응시켰다. 여기에 $10 \%$ TCA (trichloroacetic acid) 용액을 $1 \mathrm{ml}$ 가하여 $13,500 \times \mathrm{g}$ 에서 $15 \mathrm{~min}$ 동안 원심분리하여 상등액 $1 \mathrm{ml}$ 에 증류수 및 ferric chloride 각 $1 \mathrm{ml}$ 을 혼합한 후 $700 \mathrm{~nm}$ 에서 흡광도를 측정하였다. 시료의 환원력은 시료첨 가군과 대조군의 흡광도 비를 \% 값으로 환산하였다.

\section{세포배양}

사람피부섬유아세포는 $5 \% \mathrm{CO}_{2}$ 및 $37^{\circ} \mathrm{C}$ 에서 $95 \%$ 이상의 습도를 유지한 배양기에서 $10 \%$ fetal bovine serum, $2 \mathrm{mM}$ glutamine and $100 \mu \mathrm{g} / \mathrm{ml}$ penicillin -streptomycin을 포함하
는 DMEM 배지에서 배양하였다.

MTT assay

Hansen [13]의 방법에 따라 HDFs에 대한 spermidine의 세포독성을 MTT (3-(4,5-dimethyl-2-yl)-2,5-diphenyltetrazolium bromide)를 이용하여 측정하였다.

\section{In vitro 지질과산화에 대한 항산화 활성}

Spermidine을 $125,250,500$ 및 $1,000 \mu \mathrm{M}$ 의 농도가 되게 linolenic acid emulsion과 혼합한 후 $0.8 \mathrm{mM} \mathrm{H}_{2} \mathrm{O}_{2}$ 및 $0.8 \mathrm{mM}$ $\mathrm{FeSO}_{4}$ 를 혼합한 용액을 $5 \mathrm{hr}$ 동안 반응 시킨 후 $0.4 \% \mathrm{TBA}$ 를 첨가하고 $95^{\circ} \mathrm{C}$ 에서 $2 \mathrm{hr}$ 동안 반응시켜 실온에서 $10 \mathrm{~min}$ 동안 반응시켰다. 그 다음, $15: 1$ 비율의 n-butanol:pyridine 용액을 $500 \mu \mathrm{l}$ 첨가하고 $1,000 \times \mathrm{g}$ 에서 $10 \mathrm{~min}$ 동안 원심분리 하여 상등 액을 $532 \mathrm{~nm}$ 에서 흡광도를 측정하였으며 지질과산화 정도는 시료 첨가 전후의 흡광도 비를 \% 값으로 환산하였다. 분석

Hydroxyl radical에 의한 DNA 손상을 전기영동법으로

Genomic DNA는 약간 변형된 표준 과정에 따라 $\mathrm{HDFs}$ (human dermal fibroblasts) 세포로부터 추출 하였다[35]. Fenton 반응에 의하여 발생된 hydroxyl radical에 노출된 DNA 산화는 기존에 실험된 방법에 따라 수행되었다[28]. 먼 저 $100 \mu \mathrm{l}$ 의 DNA 용액에 시험농도의 spermidine, $200 \mu \mathrm{M}$ $\mathrm{FeSO}_{4}, 1 \mathrm{mM} \mathrm{H} \mathrm{O}_{2}$ 및 $50 \mu \mathrm{g} / \mathrm{ml}$ genomic DNA를 첨가하였 다. 반응 혼합물을 $30 \mathrm{~min}$ 동안 상온에서 반응시킨 후 $10 \mathrm{mM}$ $\mathrm{EDTA}$ 를 첨가하여 반응을 종결시킨다. $1 \mu \mathrm{g}$ 의 DNA를 포함하 는 $20 \mu \mathrm{l}$ 의 반응혼합물을 $1 \%$ agarose gel에서 $100 \mathrm{~V}$ 로 $30 \mathrm{~min}$ 동안 전기영동 하였다. Gel은 $1 \mathrm{mg} / \mathrm{ml}$ ethidium bromide로 염색하여 물로 세척하여 UV로 LAS3000 ${ }^{\circledR}$ image analyzer (Fujifilm Life Science, Tokyo, Japan)를 이용하여 관찰하였다.

Western blot analysis

사람피부섬유아세포에 용출 완충용액 $(50 \mathrm{mM}$ Tris - $\mathrm{HCl}$, pH 7.5, 0.4\% Nonidet P-40, $120 \mathrm{mM} \mathrm{NaCl}, 1.5 \mathrm{mM} \mathrm{MgCl}$, $2 \mathrm{mM}$ phenylmethylsulfonyl fluoride, $80 \mu \mathrm{g} / \mathrm{ml}$ leupeptin, $3 \mathrm{mM} \mathrm{NaF}$ and $1 \mathrm{mM} \mathrm{DTT}$ )을 첨가하여 $4{ }^{\circ} \mathrm{C}$ 에서 $30 \mathrm{~min}$ 동안 처리하였다. $10 \mu \mathrm{g}$ 의 세포용출액을 $10 \%$ Tris - $\mathrm{HCl}$ gel에서 전기영동 후 단백질을 전기적으로 nitrocellulose membrane 으로 전이시켰다. 그 다음 $10 \%$ skim milk를 nitrocellulose membrane에 전 처리하고 목적 단백질에 대한 1차 항체(anti-Nrf2, anti-SOD-1, anti-SOD-2, anti-SOD-3, anti-beta-actin) 를 처리한 다음 2차 항체를 처리 후, chemiluminescent ECL kit (Amersham Pharmacia Biotech)를 사용하여 목적단백질을 검출하였다. Western blot의 band는 LAS $3000^{\circledR}$ image analyzer (Fujifilm Life Science, Tokyo, Japan)를 이용하여 관찰하 
였다.

\section{통계처리}

각 실험은 3회 이상 반복실험을 통하여 그 결과를 얻어 각각 의 시료농도에 대해 평균표준편차로 나타내었다. 각 시료농 도군에 대한 유의차 검정은 대조군과 비교하여 Student's $t$ test 한 후 $p \times 0.05$ 값을 통계적으로 유의성 있는 결과로 간주하 였다.

\section{결 과}

Spermidine의 DPPH radical, Hydrogen peroxide, Hydroxyl radical 소거 효과 및 환원력

$\mathrm{DPPH}$ radical 소거법은 항산화 물질의 전자공여능으로 인 해 방향족 화합물 및 방향족 아민류에 의해 환원되어 자색이 탈색에 의해 나타내는 정도를 지표로 하여 항산화 능력을 측 정하는 방법이다. 이 실험에서 양성 대조군으로는 항산화 효 능이 잘 알려진 $0.001 \%$ 의 vitamin C를 사용 하였다. Fig. $1 \mathrm{~A}$ 에 서 보는 바와 같이 spermidine을 $125,250,500,1000 \mu \mathrm{M}$ 의 농도로 처리한 결과 DPPH radical 소거능은 500, $1000 \mu \mathrm{M}$ 에 서 농도가 증가함에 따라 소거 효과의 증가를 관찰 할 수 있었
다. 그 다음 spermidine의 $\mathrm{H}_{2} \mathrm{O}_{2}$ 소거능을 확인 하기 위하여 Hydrogen peroxide scavenging assay를 수행 하였다. 양성 대조군은 동일하게 $0.001 \%$ 의 vitamin C를 사용하였다. Fig. $1 \mathrm{~B}$ 에서 spermidine을 $125,250,500,1000 \mu \mathrm{M}$ 로 처리하여 농도 의존적으로 소거능이 증가함을 확인 할 수 있었다. Spermidine의 hydroxyl radical 소거능을 확인한 결과 Fig. 1C 에서 spermidine을 처리 하였을 때 농도가 증가 함에 따라 유의성 있게 hydroxyl radical 소거능이 증가함을 확인 할 수 있었다. 항산화 능력에서 중요한 화합물의 환원력은 항산화제 로부터 제공되는 수소 원자가 free radical과 반응하여 시작된 다. Fig. $1 \mathrm{D}$ 에서 보는 바와 같이 양성대조군은 $0.001 \%$ vitamin $\mathrm{C}$ 를 사용하였으며 $50 \%$ 의 환원력을 보여주었다.

Spermidine를 각 농도별로 처리한 결과 $500 \mu \mathrm{M}$ 의 이하의 농도에서는 환원력이 없는 것으로 나타났으나, $1,000 \mu \mathrm{M}$ 의 농도에서는 대조군과 비교하여 환원력에서 유의성이 있는 것 으로 관찰 되었다( $p \ll 0.05)$.

In vitro 수준에서 지질과산화에 대한 spermidine의 항산 화 효과

In vitro에서 지질과산화에 대한 spermidine에 의한 항산화 효과를 조사하기 위하여 linolenic acid를 Fenton반응으로 발
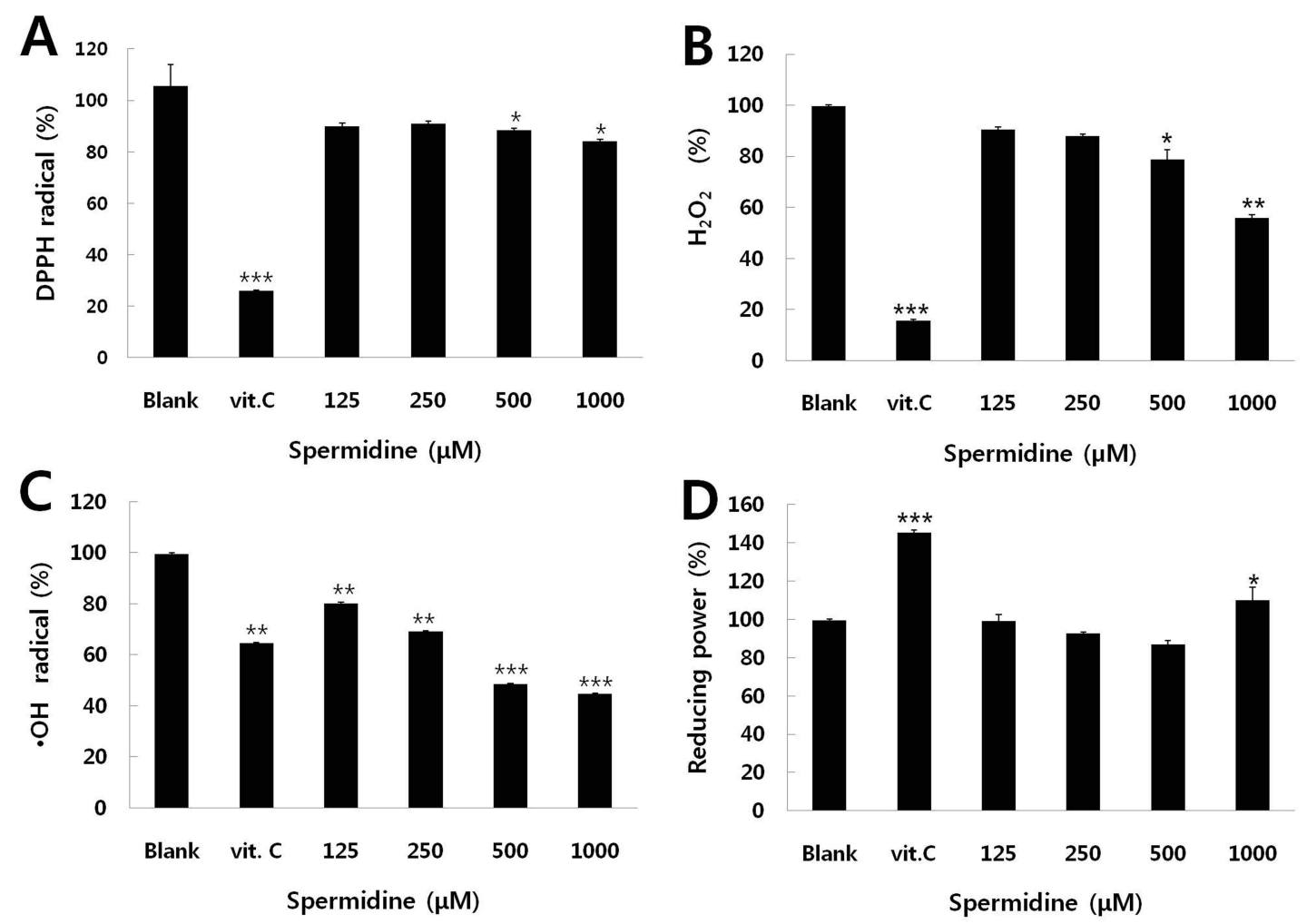

Fig. 1. The antioxidant effect of spermidine in vitro (A) The scavenging effect of spermidine on DPPH. (B) The effect of spermidine on scavenging activity of hydrogen peroxide. (C) The effect of spermidine on scavenging activity of hydroxyl radical. (D) The reducing power of spermidine. Vitamin $\mathrm{C}$ at $0.001 \%$ was used as positive control in this experiment. Data are given as means of values \pm S.D. from three independent experiments compared with control $\left({ }^{*} p<0.05,{ }^{* *} p<0.01\right)$. 
생시킨 hydroxyl radical에 노출시켰다. 먼저 hydroxyl radical 에 의한 지질과산화 확인을 위하여 기존에 알려진 친유성 항 산화제인 $0.01 \%$ 의 vitamin $\mathrm{E}$ 의 지질과산화에 대한 억제효능 을 평가한 결과, Fig. 2 에서 보여지는 바와 같이 $30 \%$ 의 지질과 산화 억제효과가 관찰되었다. Spermidine 처리군은 대조군과 비교 시 $500 \mu \mathrm{M}$ 이하의 농도에서는 지질과산화에 대한 효능 에서 유의적인 차이가 관찰되지 않았다. 반면에 spermidine은 $1,000 \mu \mathrm{M}$ 의 농도에서는 $20 \%$ 의 지질과산화 억제효과를 보여 주었다.

Hydroxyl radical에 의한 genomic DNA 산화에 대한 spermidine의 보호 효과

사람피부섬유아세포로 부터 분리한 genomic DNA를 이용 하여 Fenton 반응에 의하여 발생된 hydroxyl radical에 의한 DNA의 산화적 손상에 대한 spermidine의 보호 효과를 조사 하였다. 대조군의 genomic DNA는 Fig. 3에서 보여지는 바와 같이 hydroxyl radical에 의하여 분해되는 것을 확인 할 수 있었다. 그러나 spermidine을 첨가한 군에서는 genomic DNA 의 산화적 손상이 고농도인 $1000 \mu \mathrm{M}$ 의 농도에서 유의성 있게 억제되었다 $(p<0.01)$. Hydroxyl radical에 의한 DNA의 산화적 손상이 $1,000 \mu \mathrm{M}$ 의 농도의 spermidine에 의하여 $40 \%$ 정도 억제되는 것으로 관찰되었다.

\section{세포독성에 미치는 spermidine의 영향}

본 실험에서는 spermidine이 세포성장에 미치는 영향을 관 찰하기 위하여 세포 독성 유, 무를 조사하였다. MTT assay를 이용하여 spermidine의 세포 독성 효과를 조사하였다. Fig. 4 에서 보여지는 바와 같이 피부섬유아세포에서 $1,000 \mu \mathrm{M}$ 이하 의 농도에서 대조군과 비교하여 어떠한 독성 효과도 없는

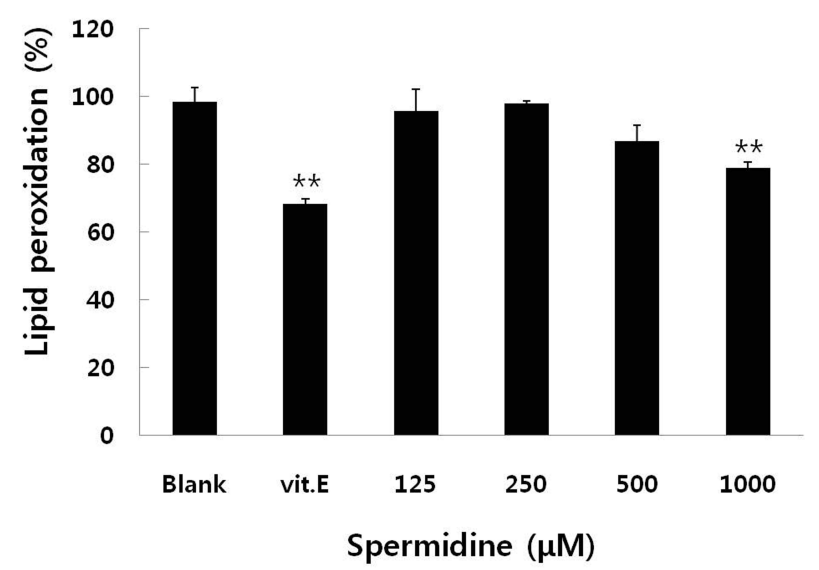

Fig. 2. The inhibitory effect of spermidine on the inhibition of peroxidation of linolenic acid. Vitamin E at $0.01 \%$ was used as positive control in this experiment. Data are given as means of values \pm S.D. from three independent experiments compared with control $\left({ }^{* *} p<0.01\right)$.
것으로 판정 되었다. 따라서, $1,000 \mu \mathrm{M}$ 이하의 농도에서 spermidine은 본 연구에서 사용된 사람피부섬유아세포에 대하여 안전하다는 것을 나타낸다.

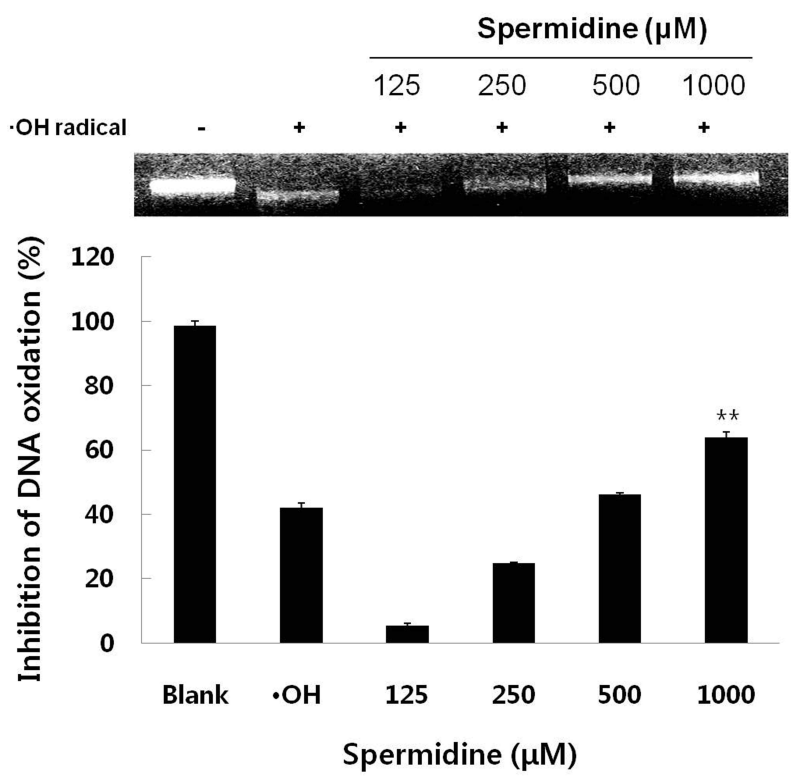

Fig. 3. Protective effect of spermidine on DNA oxidative damage induced by hydroxyl radical. Genomic DNA purified from HDFs was pre-treated with spermidine for 1 $\mathrm{hr}$ and exposed to $\bullet \mathrm{OH}$ using Fenton reaction. After $30 \mathrm{~min}$, reaction mixture containing about $1 \mu \mathrm{g}$ of DNA was electrophorased on a $1 \%$ agarose gel for $30 \mathrm{~min}$ at $100 \mathrm{~V}$ and visualized by UV light after stained with $1 \mathrm{mg} / \mathrm{ml}$ ethidium bromide. Lower panel represents respective relative density of intact genomic DNA band as percent of blank group. Data are given as means of values \pm S.D. from three independent experiments compared with control (** $p<0.01)$.

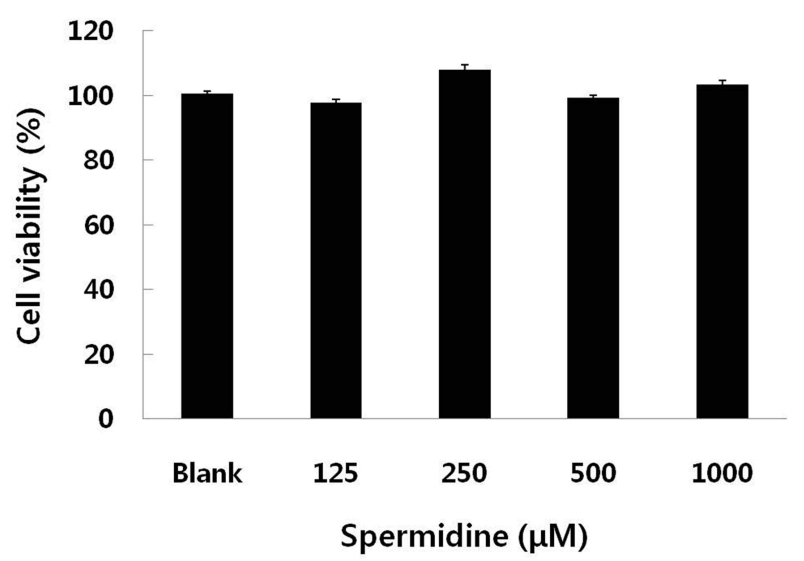

Fig. 4. Effect of spermidine on viability of human dermal fibroblasts cells. Cells were treated with spermidine at 125, 250, 500 and 1,000 $\mu \mathrm{M}$ and cell viability was determined by MTT assay after $24 \mathrm{hr}$. Data were given as means of values $\pm \mathrm{SD}$ from three independent experiments. 


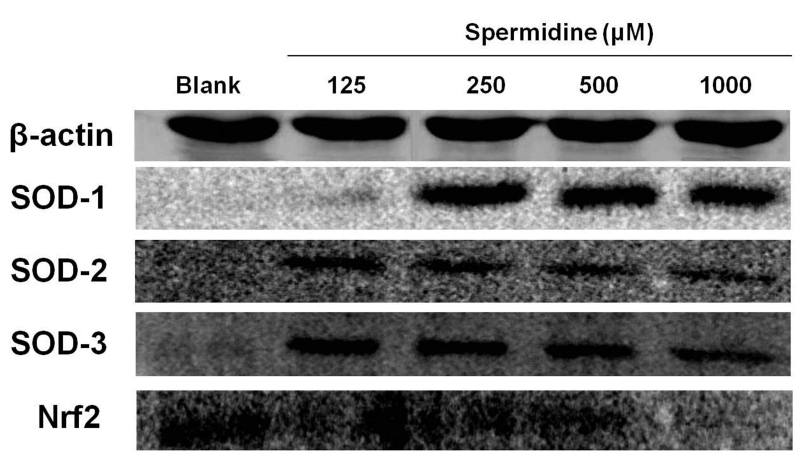

Fig. 5. Effect of spermidine on protein expressions of SOD-1, SOD-2, SOD-3 and Nrf2 in human dermal fibroblasts cells. The cells were treated with spermidine at 125, 250, 500 and 1,000 $\mu \mathrm{M}$. Western blot analysis of cell lysates was performed using antibodies as indicated. The expression of $\beta$-actin was used as a control for normalization of target proteins.

$\mathrm{HDFs}$ 에서 항산화 효과와 관련된 단백질의 발현에 대한 spermidine의 효과

항산화 효소의 발현을 조절하는데 가장 중요한 전사인자 인 Nrf2와 이 전사인자에 의하여 발현되는 3종류의 superoxide dismutase (SOD)인 항산화 효소의 단백질 발현에 대한 spermidine이 영향을 조사하였다. Fig. 5에서 보는 바와 같이 사람피부섬유아세포에 spermidine를 처리 시 Nrf2 전사인자 는 대조군에 비하여 감소되는 것으로 나타났다. Superoxide dismutases는 spermidine 처리에 대하여 다르게 반응하였으 나, 대조군에 비하여 모두 발현이 증가되었다. 먼저 $250 \mu \mathrm{M}$ 의 spermidine의 존재하에서 SOD-1이 발현되는 것이 뚜렷하게 관찰되었다. SOD-2와 SOD-3는 $125 \mu \mathrm{M}$ 의 spermidine의 존재 하에서 발현되고 농도를 증가 시 발현이 감소되는 것으로 나 타났다. 이상의 결과에서 spermidine는 전사인자인 Nrf2와는 독립적으로 대조군에 비하여 $\mathrm{SOD}$ 의 발현을 증가시키는 것을 알 수 있었다.

\section{고 찰}

다양한 산화적 스트레스 및 인체 내의 여러 가지 효소반응 에 의하여 활성 산소종이 생성된다. 이들 활성 산소 종은 생체 내의 단백질과 반응하여 기능을 상실 시키고 DNA, RNA 및 세포막과 세포소기관의 손상을 일으켜 노화 혹은 사포사멸을 유발 시킨다[14]. 이러한 이유로 활성 산소의 연구가 관심의 대상이 된다. 항산화 효과가 뛰어나다고 잘 알려진 BHT와 $\mathrm{BHA}$ 는 돌연변이 유발과 안정성의 문제로 독성이 있어 그 사 용성이 제한된다[2]. 그러므로 신체적으로 안전한 항산화제의 연구가 필요하다. Polyamine은 거의 모든 세포에 있어서 성장 과 분화에 필수적인 물질이다. 특히 spermidine은 $\mathrm{DNA}$ 합성 과정에서 중요한 역할을 하여 효소 활성에 영향을 주어 핵산
의 생합성을 조절하고 세포질 분열을 촉진하고 세포막의 안정 화, 새포 내 물질 대사 조절 등 다양한 역할을 수행 한다[6,10]. 본 논문에서는 Polyamine 중 하나인 spermidine의 산화적 스 트레스에 대해서 어떻게 작용하고 조절하는지 조사하였다. In-vitro에서 DPPH radical은 화학적으로 안정성을 가지는 자 유 라디칼을 가지고 있으며, 항산화 활성이 있는 물질을 만나 면 전자를 내주면서 라디칼이 소멸된다. 본 실험에서는 대조 군 비하여 spermidine을 첨가한 실험군에서 농도가 증가 할수 록 $\mathrm{DPPH}$ radical 소거능이 증가함을 확인 할 수 있었다. 뿐만 아니라 fenton 반응으로 생성된 hydroxyl radical과 hydrogen peroxide도 spermidine에 의해 감소됨을 확인 할 수 있었다. 이것은 spermidine은 생리적 $\mathrm{pH}$ 에서 양이온의 성질을 가지는 polycation으로 존재하며 음이온으로 하전된 부위와 결합 할 수 있다. 이러한 분자의 구조에 의해 음전하를 가진 라디칼과 결합하여 free radical을 소거할 수 있다[9]. Hydroxyl radical 은 생체 내에서 DNA와 결합하여 돌연변이 및 세포 독성을 유발 하며 생성되는 자유 라디칼을 활성화 시키며 모든 세포 에 손상을 준다[26]. spermidine이 DNA의 hydroxyl radical에 대한 보호 효과를 알아 보기 위하여 먼저 HDFs로 부터 genomic DNA를 분리하여 연구를 진행하였다. Spermidine의 농도가 증가 할수록 hydroxyl radical에 의한 산화적 스트레스 로부터 DNA의 보호 효과가 탁월한 것으로 확인 되었다. 이것 은 spermidine이 핵산의 음전하를 가진 인산기와 강하게 결합 하여 hydroxyl radical로부터 DNA를 보호 한다 다는 것을 알 수 있었다[29]. 산화적 스트레스는 여러가지 대사 질병과 세포 의 죽음에도 중요한 역할을 한다고 알려져 있다. superoxide dismutases, catalases 및 glutathionine peroxidase와 같은 효 소에 의해서 세포가 활성산소에 노출되었을 때 세포 내 radi$\mathrm{cal}$ 이 제거 된다[20,24,25]. 항산화에 중요한 전사인자인 Nrf2 로 조절 되는 SOD-1과 SOD-2, SOD-3의 발현 정도를 조사한 결과 spermidine는 전사인자인 $\mathrm{Nrf} 2$ 와는 독립적으로 $\mathrm{SOD}$ 의 발현을 증가시키는 것으로 나타났는데, 이는 사람 피부섬유아 세포에서 spermidine은 적정농도에서 SOD-1, SOD-2 및 SOD-3의 발현을 증가시켜 항산화 효과를 나타낼 수 있다는 것을 암시하고 있다. 이전의 연구에서도 spermidine이 항산화 효소에 영향을 줄 수 있다고 보고하였는데, 이러한 결과는 본 연구결과와 상충된다[38]. 그러므로 이러한 작용 기전에 의하 여 spermidine이 산화적 스트레스에 의한 질병을 예방 할 수 있는 하나의 근거 될 수 있다. 본 연구 결과를 바탕으로 spermidine의 항산화 효과를 통해 우수한 생리 활성 소재로서 기 능성 건강 식품 개발에 이바지 할 수 있다고 판단된다.

\section{감사의 글}

이 논문은 2010도 정부(교육과학기술부)의 재원으로 한국 연구재단의 지원을 받아 수행된 기초연구사업임(No. 2010- 
0005807).

\section{References}

1. Bouchereau, A., A. Aziz, F, Larher, and J. Martin-Tanguy. 1999. Polyamines and environmental challenges: recent development. Plant Sci. 140, 103-125.

2. Branen, A. 1975. Toxicology and biochemistry of butylated hydroxyanisole and butylated hydroxytoluene. J. Am Oil. Chem Soc. 52, 59-63.

3. Choi, C. W., S. C. Kim, S. S. Hwang, B. K. Choi, H. J. Ahn, M. Y. Lee, S. H. Park, and S. K. Kim. 2002. Antioxidant activity and free radical scavenging capacity between Korean medicinal plants and flavonoids by assay-guided comparison. Plant Sci. 163, 1161-1168.

4. Choi, C. S., E. S. Song, J. S. Kim, and M. H. Kang. 2003. Antioxidative activities of Castanea crenata Flos. methanol extracts. Korean J. Food Sci. Technol. 35, 1216-1220.

5. Cuevas, J., R. Lopez-Cobollo, R. Alcazar, X. Zarza, C. Koncz, T. Altabella, J. Salinas, A. Tiburcio, and A. Ferrando. 2008. Putrescine is involved in Arabidopsis freezing tolerance and cold acclimation by regulating abscisic acid levels in response to low temperature. Plant Physiol. 148, 1094-1105.

6. Davies, P. 2010. The plant hormones: their nature, occurrence, and functions. Plant Hormones A, 1-15.

7. Duan, J., J. Li, S. Guo, and Y. Kang. 2008. Exogenous spermidine affects polyamine metabolism in salinity-stressed Cucumis sativus roots and enhances short-term salinity tolerance. J. Plant Physiol. 165, 1620-1635.

8. Eisenberg, T., H. Knauer, A. Schauer, S. Buttner, C. Ruckenstuhl, D. Carmona-Gutierrez, J. Ring, S. Schroeder, C. Magnes, and L. Antonacci. 2009. Induction of autophagy by spermidine promotes longevity. Nat. Cell Biol. 11, 1305-1314.

9. Feuerstein, B. and L. Marton. 1989. Specificity and binding in polyamine/nucleic acid interactions. pp. 109-124, In Bachrach, U. and Y. M. Heimer (eds.), The Physiology of Polyamines, CRC Press, Boca Raton, Florida.

10. Galston, A. 2001. Plant biology-Retrospect and prospect. Curr. Sci. 80, 143-152.

11. Groppa, M., M. Benavides, and M. Tomaro. 2003. Polyamine metabolism in sunflower and wheat leaf discs under cadmium or copper stress. Plant Sci. 164, 293-299.

12. Ha, H., N. Sirisoma, P. Kuppusamy, J. Zweier, P. Woster, and R. Casero. 1998. The natural polyamine spermine functions directly as a free radical scavenger. Proc. Natl. Acad Sci. USA 95, 11140-11145.

13. Hansen, M., S. Nielsen, and K. Berg. 1989. Re-examination and further development of a precise and rapid dye method for measuring cell growth/cell kill. J. Immund. Methods 119, 203-210.

14. Harman, D. 1956. A theory based on free radical and radiation chemistry. J. Gerontol. 11, 298-300.

15. Hasani-Ranjbar, S., B. Larijani, and M. Abdollahi. 2009. A systematic review of the potential herbal sources of future drugs effective in oxidant-related diseases. Inflamm Allergy Drug Targets 8, 2-10.

16. Imai, J., N. Ide, S. Nagae, T. Moriguchi, H. Matsuura, and Y. Itakura. 1994. Antioxidant and radical scavenging effects of aged garlic extract and its constituents. Planta Med 60, 417-420.

17. Jang, M., L. Cai, G. Udeani, K. Slowing, C. Thomas, C. Beecher, H. Fong, N. Farnsworth, A. Kinghorn, and R. Mehta. 1997. Cancer chemopreventive activity of resveratrol, a natural product derived from grapes. Science 275, 218-220.

18. Khan, A., P. Di Mascio, M. Medeiros, and T. Wilson. 1992. Spermine and spermidine protection of plasmid DNA against single-strand breaks induced by singlet oxygen. Proc. Natl. Acad Sci. USA 89, 11428-11430.

19. Kitada, M., Y. Naito, K. Igarashi, S. Hirose, Y. Kanakubo, and H. Kitagawa. 1981. Possible mechanism of inhibition by polyamines of lipid peroxidation in rat liver microsomes. Res. Commun. Chem Pathol. Pharmacol. 33, 487-497.

20. Krishna, M., W. DeGraff, O. Hankovszky, C. Sar, T. Kalai, J. Jeko, A. Russo, J. Mitchell, and K. Hideg. 1998. Studies of structure- activity relationship of nitroxide free radicals and their precursors as modifiers against oxidative damage. J. Med Chem 41, 3477-3492.

21. Kwon, G. J., D. S. Choi, and M. H. Wang. 2007. Biological activities of hot water extracts from euonymus alatus leaf. Korean J. Food Sci. Technol. 39, 569-574.

22. Løvaas, E. 1995. Hypothesis: spermine may be an important epidermal antioxidant. Medical Hypotheses 45, 59-67.

23. Li, H., S. Yashiki, J. Sonoda, H. Lou, S. Ghosh, J. Byrnes, C. Lema, T. Fujiyoshi, M. Karasuyama, and S. Sonoda. 2000. Green tea polyphenols induce apoptosis in vitro in peripheral blood T lymphocytes of adult T-cell leukemia patients. Cancer Sci. 91, 34-40.

24. Lightfoot, T., C. Skibola, A. Smith, M. Forrest, P. Adamson, G. Morgan, P. Bracci, E. Roman, M. Smith, and E. Holly. 2006. Polymorphisms in the oxidative stress genes, superoxide dismutase, glutathione peroxidase and catalase and risk of non-Hodgkin's lymphoma. Haematologica. 91, 1222-12227.

25. Looi, M., A. Mohd Dali, S. Md Ali, W. Wan Ngah, and Y. Mohd Yusof. 2008. Oxidative damage and antioxidant status in patients with cervical intraepithelial neoplasia and carcinoma of the cervix. Eur. J. Cancer Prev. 17, 555-560.

26. Manian, R., N. Anusuya, P. Siddhuraju, and S. Manian. 2008. The antioxidant activity and free radical scavenging potential of two different solvent extracts of Camellia sinensis (L.) O. Kuntz, Ficus bengalensis L. and Ficus racemosa L. Food Chem 107, 1000-1007.

27. Medic-Saric, M., V. Rastija, M. Boji, and Z. Male. 2009. From functional food to medicinal product: Systematic approach in analysis of polyphenolics from propolis and wine. Nutr. J. 8, 33.

28. Milne, L., P. Nicotera, S. Orrenius, and M. Burkitt. 1993. Effects of glutathione and chelating agents on copper-mediated DNA oxidation: pro-oxidant and antioxidant properties 
of glutathione. Arch Biochem Biophys. 304, 102-109.

29. Moinard, C., L. Cynober, and J. de Bandt 2005. Polyamines: metabolism and implications in human diseases. Clin. Nutr. 24, 184-197.

30. Mozdzan, M., J. Szemraj, J. Rysz, R. Stolarek, and D. Nowak. 2006. Anti-oxidant activity of spermine and spermidine re-evaluated with oxidizing systems involving iron and copper ions. Int. J. Biochem Cell Biol. 38, 69-81.

31. Ohnishi, N. and T. Yokoyama. 2004. Interactions between medicines and functional foods or dietary supplements. Keio. J. Med 53, 137-150.

32. Oyaizu, M. 1986. Studies on products of the browning reaction. Antioxidative activities of browning reaction products prepared from glucosamine. Jpn. J. Nutr. 44, 307-315.

33. Reddy, A. and B. Lokesh. 1994. Studies on the inhibitory effects of curcumin and eugenol on the formation of reactive oxygen species and the oxidation of ferrous iron. Mol. Cell Biochem 137, 1-8.

34. Rider, J., A. Hacker, C. Mackintosh, A. Pegg, P. Woster, and R. Casero. 2007. Spermine and spermidine mediate pro- tection against oxidative damage caused by hydrogen peroxide. Amino Acids 33, 231-240.

35. Sambrook, J., E. Fritsch, and T. Maniatis. 1989. Molecular cloning: A laboratory manual. pp. 1-344, 3th eds., Cold Spring Harbor Laboratory Press. New York.

36. Valko, M., D. Leibfritz, J. Moncol, M. Cronin, M. Mazur, and J. Telser. 2007. Free radicals and antioxidants in normal physiological functions and human disease. Int. J. Biochem Cell Biol. 39, 44-84.

37. Yang, Y. H., Y. J. Kim, and H. Y. Chung. 2001. Peroxynitrite and hydroxyl radical scavenging activity of dihydroxybenzaldehydes. Korean J. Gerontol. 11, 24-28.

38. Yoshiki, Y., M. Kinumi, T. Kahara, and K. Okubo. 1996. Chemiluminescence of soybean saponins in the presence of active oxygen species. Plant Sci. 116, 125-129.

39. Zhao, H. and H. Yang. 2008. Exogenous polyamines alleviate the lipid peroxidation induced by cadmium chloride stress in Malus hupehensis Rehd. Sci. Hortic-Amsterdam 116, 442-447.

\section{초록 : 사람피부섬유아세포에서 산화적 스트레스에 대한 항산화 활성을 가진 spermidine의 억제효과 \\ 박인환 · 김문무* \\ (동의대학교 화학과)}

Spermidine은 spermine의 전구체로 역할을 하는 putrescine로부터 합성되는 polycation의 한 형태이다. 최근 에 spermidine는 수명연장에 중요한 역할을 하는 하나의 polyamine으로 알려져 있다. Hydroxyl radical, superoxide 및 hydrogen peroxide와 같은 활성산소(ROS)는 노화뿐만 아니라 다양한 병원성 과정에서 관여한다고 보 고되고 있다. DPPH radical, $\mathrm{H}_{2} \mathrm{O}_{2}$ 및 hydroxyl radical에 대한 spermidine의 소거활성과 산화적 스트레스와 관련 된 DNA oxidation에 대한 보호 효과가 in-vitro에서 평가되었다. Spermidine은 $500 \mu \mathrm{M}$ 이상에서 DPPH radical와 $\mathrm{H}_{2} \mathrm{O}_{2}$ 에 대한 소거 효과를 보여주었다. 특히 활성산소종 중에서 spermidine는 hydroxyl radical에 대한 효과가 탁월하였다. 뿐만 아니라, spermidine는 $500 \mu \mathrm{M}$ 에서 DNA oxidation에 대해서도 뚜렷한 보호 효과를 나타내었 다. 더욱이 사람피부섬유아세포에서 superoxide dismutase와 같은 항산화 관련 단백질의 발현이 대조군과 비교 시 spermidine 존재 하에 증가하였다. 이상의 결과로부터 spermidine은 암, 노화 및 염증을 포함하는 활성산소와 관련 있는 질병들을 예방하기 위한 항산화제로 이용될 수 있을 것이다. 